\title{
Erratum to: Econometric model of viability/profitability of ongrowing sharp snout sea bream (Diplodus puntazzo) in sea cages
}

\section{J. García García • B. García García}

\section{Erratum to: Aquacult Int \\ DOI: $10.1007 / \mathrm{s} 10499-009-9311-1$}

Unfortunately, the author and co-author's names have been published incorrectly. The correct version is J. García García and B. García García and not García J. García and García B. García as earlier published.

The online version of the original article can be found under doi:10.1007/s10499-009-9311-1.

J. García García $(\bowtie) \cdot$ B. García García

I.M.I.D.A. C/Mayor, s/n., 30150 La Alberca (Murcia), España

e-mail: jose.garcia21@carm.es 